\title{
New host plants records of Bactrocera carambolae Drew \& Hancock, 1994 and Anastrepha spp. (Diptera: Tephritidae) in Brazil
}

\author{
Andressa P. D. Belo ${ }^{1 \oplus}$, Leide $M$. da S. Rocha ${ }^{1 \oplus}$, Jackson M. G. Corrêa ${ }^{1 \oplus}$, \\ Ricardo M. dos A. Ferreira ${ }^{1 \oplus}$, Salustiano V. da Costa-Neto ${ }^{2(}$, Maria do S. M. de Sousa ${ }^{3{ }^{(}}$, \\ Ricardo Adaime $\mathrm{A}^{4=0}=\mathbb{0}$, Lailson do N. Lemos ${ }^{2}$
}

${ }^{1}$ Universidade Federal do Amapá (UNIFAP), Campus Mazagão, AP, Brazil. ${ }^{2}$ Instituto de Pesquisas Científicas e Tecnológicas do Amapá (IEPA), Macapá, AP, Brazil. ${ }^{3}$ Universidade Federal do Amapá (UNIFAP), Campus Marco Zero, Macapá, AP, Brazil. ${ }^{4}$ Embrapa Amapá, Macapá, AP, Brazil.

表=-Corresponding author: ricardo.adaime@embrapa.br

Edited by: Thiago de A. Mastrangelo

Received: September 14, 2020. Accepted: November 24, 2020. Published: December 21, 2020.

Abstract. In this work we report five new host plants of Bactrocera carambolae Drew \& Hancock, 1994 as well as new records of hosts of Anastrepha bahiensis Lima, 1937, Anastrepha fraterculus (Wiedemann, 1830), and Anastrepha striata Schiner, 1868 from samplings carried out in Mazagão county, Amapá-Brazil.

Keywords: carambola fruit fly, fruit production, quarantine pest, Amazon.

Bactrocera carambolae Drew \& Hancock, 1994 (Diptera: Tephritidae), native to Asia, is an invading species in South America, where it was collected for the first time in 1975, in Paramaribo, Suriname (Castilho et al. 2019). Its first detection in Brazil was in 1996, in Oiapoque county, state of Amapá (Silva et al. 2004). Currently, the species occurs in some locations in the states of Amapá, Pará and Roraima and is under official control by the Ministry of Agriculture and Food Supply (Brazil 2018).

The occurrence of $B$. carambolae in Brazil is one of the main phytosanitary barrier for fruit exports, since there are quarantine restrictions imposed by importing countries on the purchase of products from regions where the pest occurs (Silva et al. 2004; Godoy et al. 2011; Lemos et al. 2014; Ferreira \& Rangel 2015; Miranda \& Adami 2015).

Despite being known as carambola fruit fly, B. carambolae is a polyphagous species (Silva et al. 2004; Sauers-Müller 2005; Adaime et al. 2016a). In Southeast Asia, Allwood et al. (1999) reported the occurrence of carambola fruit fly on 75 plant species in 26 families. In South America, hosts were recorded in four countries: 1) French Guiana (France) - 24 hosts in 11 families (Malavasi et al. 2013; Vayssières et al. 2013); 2) Suriname - 23 hosts in 11 families (Sauers-Müller 1991; Sauers-Müller 2005; Malavasi et al. 2013); 3) Brazil - 21 hosts in 9 families, all of them in the state of Amapá (Adaime et al. 2016a); and 4) Guyana - 4 hosts in 4 families (Malavasi et al. 2013).

Taking into account that is necessary to consider a natural host only the plant species whose fruit is found to be unmistakably infested under totally natural field conditions (Aluja \& Mangan 2008), this work aimed to report new host plants of $B$. carambolae and species of Anastrepha Schiner, 1868 in Brazil.

From April 2018 to March 2020, a sampling of fruits from plants potentially host of fruit flies was carried out in the municipality of Mazagão, state of Amapá, Brazil. The fruits were collected randomly, depending on availability, according to the phenology of each species, being obtained directly from the plants. The collected samples were packed in plastic trays $(16 \times 30 \mathrm{~cm})$ and transported in stackable plastic boxes to the Entomology Nucleus Laboratory at the Federal University of Amapá, Campus Mazagão. In the laboratory, we followed the procedures recommended by Silva et al. (2011) for grouped fruit samples. The fruits were counted, weighed and placed in plastic trays on a thin layer of moist sand. The trays were covered with organza attached by elastic alloy. The collected material was examined every three days and the puparia found were removed and transferred to transparent plastic containers containing a thin layer of moistened vermiculite. The plastic containers were covered with organza and a vented lid, being inspected daily. The humidity in the trays and in the containers was maintained by replacing the water. The fruit flies that emerged were stored in glass flasks containing $70 \%$ etanol, for later identification.

The identification of B. carambolae was based on Zucchi (2000). Specimens of Anastrepha were identified using the illustrated identification key published by Zucchi et al. (2011). Only females were used for identification, which was performed by examination of everted aculei, using a stereomicroscope and optical microscope (40×). Other characteristics were also observed, including wing pattern, mesonotum, mediotergite, and subscutellum.

We collected 17 samples (683 fruits, $10.61 \mathrm{~kg}$ ) in urban and rural communities in the municipality of Mazagão, in 11 of them (64.7\%) there was infestation by fruit fly (Tab. 1). In total, 1,268 puparia were obtained, from which emerged specimens of $B$. carambolae $(340++$ $351 \hat{)})$ and Anastrepha spp. $(20 \bigcirc+18 \hat{\jmath})$. The species obtained were $B$. carambolae, Anastrepha bahiensis Lima, 1937 Anastrepha fraterculus (Wiedemann, 1830), Anastrepha obliqua (Macquart, 1835) and Anastrepha striata Schiner, 1868 (Diptera: Tephritidae) (Tab. 2).

Bactrocera carambolae infested fruits of Averrhoa bilimbi L. (Oxalidaceae), Calycolpus goetheanus (Mart. ex DC.) O.Berg (Myrtaceae), Spondias purpurea L. (Anacardiaceae), Syzygium jambos (L.) Alston and Syzygium samarangense (Blume) Merr. \& L. M. Perry (Myrtaceae) (Tab. 2). This is the first record of these plant species as hosts of B. carambolae in Brazil. After these records, the pest has 26 confirmed host plant species (in 9 families) in the country, five more than in the list presented by Adaime et al. (2016a). Myrtaceae is the family with more host species reported (9).

Spondias purpurea had previously been reported as host of $B$. carambolae in French Guiana and Suriname; S. jambos in Suriname; 
and S. samarangense in Guyana, Suriname and French Guiana (SauersMüller 1991; Sauers-Müller 2005; Vayssières et al. 2013). The species A. bilimbi, S. jambos and S. samarangense are part of the host range of B. carambolae in Southeast Asia (Allwood et al. 1999). In turn, C. goetheanus was never reported as a host of $B$. carambolae. Interestingly, this plant is native of Neotropical region and occurs naturally in periurban forests, revealing the adaptative capacity of $B$. carambolae to native plant species, as had been demonstrated by Lemos et al. (2014).

Among our results, the high infestation rates in S. jambos (765.3 puparia/kg in Mazagão Novo and 1,111.1 puparia/kg in Mazagão Velho) exclusively by $B$. carambolae are noteworthy (Tab. 2). Until then, the greatest infestations by $B$. carambolae in samples collected in Amapá were 559.4 puparia/kg in Chrysobalanus icaco L. (Chrysobalanaceae) and 620.7 puparia/kg in Malpighia emarginata DC. (Malpighiaceae), recorded by Lemos et al. (2014). Averrhoa bilimbi presented only two infested samples among the eight collected, with low rate of infestation (9.2 puparia/kg).

In addition to the results for $B$. carambolae, this work presents other findings: 1) $C$. goetheanus constitutes a new host record of $A$. fraterculus and $A$. striata in Brazil; 2) S. purpurea constitutes a new host record of $A$. bahiensis in Brazil. After these records, $A$. fraterculus, A. striata and A. bahiensis have 117, 29 and 16 hosts reported in Brazil, respectively (Zucchi \& Moraes 2008; Adaime et al. 2016b).

Considering the socioeconomic expression of B. carambolae for Brazilian fruit production (Silva et al. 2004; Godoy et al. 2011; Lemos et al. 2014; Ferreira \& Rangel 2015; Miranda \& Adami 2015), it is imperative that studies aimed at registering new host plants for this pest continue to be carried out and the results generated can be used to adopt more targeted and effective control measures.

Table 1. Plant species sampled in Mazagão county, State of Amapá, Brazil (from April 2018 to March 2020).

\begin{tabular}{|c|c|c|c|c|c|c|c|c|c|}
\hline \multirow{2}{*}{ Communities } & \multirow{2}{*}{ Families } & \multirow{2}{*}{ Sampled species } & \multirow{2}{*}{ CS/IS* } & \multirow{2}{*}{$\begin{array}{l}\text { Fruits } \\
\text { (n) }\end{array}$} & \multirow{2}{*}{$\begin{array}{l}\text { Mass } \\
(\mathrm{kg})\end{array}$} & \multirow{2}{*}{$\begin{array}{l}\text { Puparia } \\
\text { (n) }\end{array}$} & \multicolumn{2}{|c|}{ Emergence } & \multirow{2}{*}{$\begin{array}{l}\text { Infestation } \\
\text { puparia/kg }\end{array}$} \\
\hline & & & & & & & $\mathbf{n}$ & $\%$ & \\
\hline \multirow[t]{5}{*}{ Mazagão Novo } & Anacardiaceae & Spondias purpurea L. & $1 / 1$ & 46 & 0.50 & 37 & 18 & 48.6 & 74.0 \\
\hline & Myrtaceae & $\begin{array}{l}\text { Calycolpus goetheanus (Mart. ex DC.) } \\
\text { O. Berg. }\end{array}$ & $1 / 1$ & 59 & 0.26 & 45 & 20 & 44.4 & 173.1 \\
\hline & & Syzygium jambos (L.) Alston & $2 / 2$ & 66 & 1.18 & 903 & 547 & 60.6 & 765.3 \\
\hline & & $\begin{array}{l}\text { Syzygium samarangense (Blume) } \\
\text { Merr. \& L. M. Perry }\end{array}$ & $1 / 1$ & 97 & 2.39 & 5 & 3 & 60.0 & 2.1 \\
\hline & Oxalidaceae & Averrhoa bilimbi L. & $4 / 2$ & 106 & 2.61 & 24 & 24 & 100 & 9.2 \\
\hline \multirow[t]{2}{*}{ Mazagão Velho } & Myrtaceae & Syzygium jambos (L.) Alston & $1 / 1$ & 8 & 0.18 & 200 & 86 & 43.0 & $1,111.1$ \\
\hline & Oxalidaceae & Averrhoa bilimbi L. & $2 / 0$ & 53 & 1.04 & 0 & 0 & - & - \\
\hline \multirow[t]{3}{*}{ Carvão } & Anacardiaceae & Spondias purpurea L. & $1 / 1$ & 44 & 0.63 & 31 & 18 & 58.1 & 49.2 \\
\hline & Myrtaceae & $\begin{array}{l}\text { Calycolpus goetheanus (Mart. ex DC.) } \\
\text { O. Berg. }\end{array}$ & $1 / 1$ & 81 & 0.55 & 15 & 6 & 40.0 & 27.3 \\
\hline & Oxalidaceae & Averrhoa bilimbi L. & $2 / 0$ & 105 & 1.07 & 0 & 0 & - & - \\
\hline Camaipi & Anacardiaceae & Spondias purpurea L. & $1 / 1$ & 18 & 0.20 & 8 & 7 & 87.5 & 40.0 \\
\hline Total & - & - & $17 / 11$ & 683 & 10.61 & 1,268 & 729 & - & - \\
\hline
\end{tabular}

${ }^{*} \mathrm{CS}=$ Collected Samples, IS = Infested Samples

Table 2. Hosts of fruit flies species in Mazagão county, State of Amapá, Brazil (from April 2018 to March 2020).

\begin{tabular}{|c|c|c|}
\hline Communities & Hosts species* & Fruit flies species \\
\hline \multirow[t]{5}{*}{ Mazagão Novo } & Averrhoa bilimbi L. ${ }^{a}$ & Bactrocera carambolae $(7 q+17 \delta)$ \\
\hline & Calycolpus goetheanus (Mart. ex DC.) O. Berg ${ }^{\mathrm{b}}$ & $\begin{array}{l}\text { Bactrocera carambolae }\left(6 q+7 \delta^{\lambda}\right) \\
\text { Anastrepha fraterculus }\left(3 q+4 \delta^{\lambda}\right)\end{array}$ \\
\hline & Spondias purpurea L. ${ }^{c}$ & $\begin{array}{l}\text { Anastrepha fraterculus }(8+) \\
\text { Anastrepha bahiensis }(2+) \\
\text { Anastrepha obliqua }(1+) \\
\text { Anastrepha spp. }\left(7 \delta^{\lambda}\right)\end{array}$ \\
\hline & Syzygium jambos (L.) Alston ${ }^{d}$ & Bactrocera carambolae $\left(266 q+281 \delta^{\lambda}\right)$ \\
\hline & Syzygium samarangense (Blume) Merr. \& L. M. Perrye & Bactrocera carambolae $(1 q+2 \hat{\jmath})$ \\
\hline Mazagão Velho & Syzygium jambos (L.) Alston ${ }^{f}$ & Bactrocera carambolae $\left(51 q+35{ }^{\lambda}\right)$ \\
\hline \multirow[t]{2}{*}{ Carvão } & Calycolpus goetheanus (Mart. ex DC.) O. Bergg & $\begin{array}{l}\text { Anastrepha fraterculus }(1+) \\
\text { Anastrepha striata }(2+) \\
\text { Anastrepha spp. }(3 \hat{)})\end{array}$ \\
\hline & Spondias purpurea L. ${ }^{\mathrm{h}}$ & Bactrocera carambolae $(9 q+9 \hat{\jmath})$ \\
\hline Camaipi & Spondias purpurea L.' & Anastrepha fraterculus $(3 q+4 \lesssim)$ \\
\hline
\end{tabular}

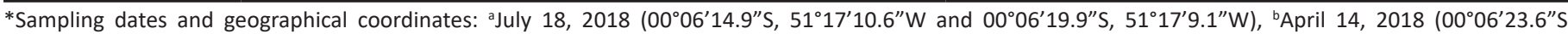
$\left.51^{\circ} 17^{\prime} 15.9^{\prime \prime} \mathrm{W}\right)$, cJanuary 31, $2019\left(00^{\circ} 06^{\prime} 18.8^{\prime \prime} \mathrm{S}, 51^{\circ} 16^{\prime} 41.8^{\prime \prime} \mathrm{W}\right)$, dApril 14, $2018\left(00^{\circ} 06^{\prime} 58.7^{\prime \prime} \mathrm{S}, 51^{\circ} 17^{\prime} 46.3^{\prime \prime} \mathrm{W}\right.$ and $\left.00^{\circ} 06^{\prime} 23.0^{\prime \prime} \mathrm{S}, 51^{\circ} 17^{\prime} 15.8^{\prime \prime} \mathrm{W}\right)$, eFebruary 20 , $2020\left(00^{\circ} 05^{\prime} 28.4^{\prime \prime} \mathrm{S}, 51^{\circ} 16^{\prime} 34.2^{\prime \prime} \mathrm{W}\right),{ }^{\mathrm{f}} \mathrm{May} 2,2018\left(00^{\circ} 13^{\prime} 10.8^{\prime \prime} \mathrm{S}, 51^{\circ} 26^{\prime} 00.2^{\prime \prime} \mathrm{W}\right),{ }^{\circ}$ March $10,2020\left(00^{\circ} 11^{\prime} 48.3^{\prime \prime} \mathrm{S}, 51^{\circ} 21^{\prime} 59.6^{\prime \prime} \mathrm{W}\right),{ }^{\mathrm{h}} \mathrm{May} 3,2018\left(00^{\circ} 10^{\prime} 57.5^{\prime \prime} \mathrm{S}\right.$, $\left.51^{\circ} 21^{\prime} 17.5^{\prime \prime} \mathrm{W}\right)$, 'May 16, $2018\left(00^{\circ} 08^{\prime} 15.5^{\prime \prime} \mathrm{S}, 51^{\circ} 21^{\prime} 0.8^{\prime \prime} \mathrm{W}\right)$.

\section{Acknowledgments}

Amapá Research Support Foundation and to the National Council for Scientific and Technological Development - CNPq, for financing the Project "Bioecologia de moscas-das-frutas (Diptera: Tephritidae e Lonchaeidae) e seus inimigos naturais no município de Mazagão, Amapá, Brasil", under the "First Projects Program". National Council for Scientific and Technological Development - CNPq, for the Research
Productivity Fellowship granted to Ricardo Adaime. Ministry of Agriculture and Food Supply for authorizing publication of data pertaining to the carambola fruit fly.

\section{Authors' Contributions}

APDB, LMSR and JMGC contributed to the field and laboratory work, taxonomic identification of fruit flies, critical reviews, and 
adding intellectual content to the manuscript. MSMS contributed to the taxonomic identification of fruit flies, critical reviews and adding intellectual content to the manuscript. RA, LNL and RMAF contributed to the concept and design of the study, data analysis and interpretation and manuscript preparation. SVCN contributed to the identification of botanical material, critical reviews and adding intellectual content to the manuscript.

\section{References}

Adaime, R.; Jesus-Barros, C. R.; Bariani, A.; Lima, A. L.; Cruz, K. R.; Carvalho, J. P. (2016a) Novos registros de hospedeiros da moscada-carambola (Bactrocera carambolae) no estado do Amapá, Brasil. Embrapa Amapá (Comunicado Técnico 146). https://ainfo. cnptia.embrapa.br/digital/bitstream/item/155953/1/CPAF-AP2016-COT-146-Hospedeiros-mosca-v5.pdf. Access on: 12.viii.2020.

Adaime, R.; Sousa, M. S. M.; Pereira, J. F. (2016b) Anastrepha species and their host in the Brazilian Amazon. http://anastrepha.cpafap. embrapa.br. Access on: 12.viii.2020.

Allwood, A. J.; Chinajariyawong, A.; Vkritsaneepaiboon, S.; Drew, R. A. I., Hamacek, E. L., Hancock, D. L., Hengsawad, C., Jipanin, J. C., Jirasurat, M., Krong, C. K., et al. (1999) Host plant records for fruit flies (Diptera: Tephritidae) in Southeast Asia. The Raffles Bulletin of Zoology, 47(7): 1-92.

Aluja, M.; Mangan, R. L. (2008) Fruit Fly (Diptera: Tephritidae) Host Status Determination: Critical Conceptual, Methodological, and Regulatory Considerations. Annual Review of Entomology, 53(1): 473-502. doi: 10.1146/annurev.ento.53.103106.093350

Brazil (2018) Ministério da Agricultura, Pecuária e Abastecimento. Instrução Normativa n॰ 38, de 1 de outubro de 2018. Diário Oficial [da] República Federativa do Brasil, Brasília, DF, 2 out. 2018. Seção 1. http://www.in.gov.br/materia/-/asset_publisher/Kujrw0TZC2Mb/ content/id/43461167/do1-2018-10-02-instrucao-normativa-n-38de-1-de-outubro-de-2018-43461024. Access on: 12.viii.2020.

Castilho, A. P.; Pasinato, J.; Santos, J. E. V.; Costa, A. S.; Nava, D. E.; Jesus, C. R.; Adaime, R. (2019) Biology of Bactrocera carambolae (Diptera Tephritidae) on four hosts. Revista Brasileira de Entomologia. 63(4): 302-307. doi: 10.1016/j.rbe.2019.09.002

Ferreira, M. E.; Rangel, P. H. N. (2015) Melhoramento genético preventivo: obtenção de estoques genéticos resistentes a pragas quarentenárias de alto risco para a agricultura brasileira. In: Sugayama, R. L.; Silva, M. L.; Silva, S. X. B.; Ribeiro, L. C.; Rangel, L. E. P. (Eds.), Defesa vegetal: fundamentos, ferramentas, políticas e perspectivas, pp. 275-292. Belo Horizonte: Sociedade Brasileira de Defesa Agropecuária.

Godoy, M. J. S.; Pacheco, W. S. P.; Malavasi, A. (2011) Moscas-das-frutas quarentenárias para o Brasil. In: Silva, R. A.; Lemos, W. P.; Zucchi, R. A. (Eds.), Moscas-das-frutas na Amazônia brasileira: diversidade, hospedeiros e inimigos naturais, pp. 111-132. Macapá: Embrapa Amapá.

Lemos, L. N.; Adaime, R.; Jesus-Barros, C. R.; Deus, E. G. (2014) New hosts of Bactrocera carambolae (Diptera: Tephritidae) in Brazil. Florida Entomologist, 97(2): 841-847. doi: 10.1653/024.097.0274

Malavasi, A.; Midgarden, D.; Sauers-Müller, A. van. (2013) Manual for the control of the carambola fruit fly in South America: operations manual. In: Sauers-Müller, A. van.; Signoretti, J. G. (Eds.), Paramaribo: Carambola Fruit Fly Programme. https:// www.researchgate.net/publication/317182807_Manual_for the control_of_the_Carambola_fruit_fly_in_South_America. Access on: 22.viii.2020.

Miranda, S. H. G.; Adami, A. C. O. (2015) Métodos quantitativos na avaliação de risco de pragas. In: Sugayama, R. L.; Silva, M. L.; Silva, S. X. B.; Ribeiro, L. C.; Rangel, L. E. P. (Eds.), Defesa vegetal: fundamentos, ferramentas, políticas e perspectivas, pp. 183-203. Belo Horizonte: Sociedade Brasileira de Defesa Agropecuária.

Sauers-Müller, A. van. (1991) An overview of the carambola fruit fly Bactrocera species (Diptera: Tephritidae), found recently in Suriname. Florida Entomologist, 74(3): 432-440. doi: $10.2307 / 3494837$
Sauers-Müller, A. van. (2005) Host plants of the carambola fruit fly, Bactrocera carambolae Drew \& Hancock (Diptera: Tephritidae), in Suriname, South America. Neotropical Entomology, 34(2): 203214. doi: 10.1590/S1519-566X2005000200008

Silva, R. A.; Deus, E. G.; Raga, A.; Pereira, J. D. B.; Souza-Filho, M. F.; Costa Neto, S. V. (2011) Monitoramento de moscas-das-frutas na Amazônia: amostragem de frutos e uso de armadilhas. In: Silva, R. A.; Lemos, W. P.; Zucchi, R. A. (Eds.), Moscas-das-frutas na Amazônia brasileira: diversidade, hospedeiros e inimigos naturais, pp. 33-50. Macapá: Embrapa Amapá.

Silva, R. A.; Jordão, A. L.; Sá, A. L. N.; Oliveira, M. R. V. (2004) Moscada-carambola: uma ameaça à fruticultura brasileira. Embrapa Amapá (Circular Técnica 31). https://ainfo.cnptia.embrapa.br/ digital/bitstream/CPAF-P/8417/1/Circular200431.PDF. Access on: 12.viii.2020.

Vayssières, J. F.; Cayol, J. P.; Caplong, P.; Séguret, J.; Midgarden, D.; Sauers-Müller, A. van.; Zucchi, R.; Uramoto, K.; Malavasi, A. (2013) Diversity of fruit fly (Diptera: Tephritidae) species in French Guiana: their main host plants and associated parasitoids during the period 1994-2003 and prospects for management. Fruits, 68(3): 219-243. doi: $10.1051 /$ fruits/2013070

Zucchi, R. A. (2000) Taxonomia. In: Malavasi, A.; Zucchi, R. A. (Eds.), Moscas-das-frutas de Importância Econômica no Brasil: Conhecimento Básico e Aplicado, pp. 13-24. Ribeirão Preto: Holos.

Zucchi, R. A.; Uramoto, K.; Souza-Filho, M. F. (2011) Chave ilustrada para as espécies de Anastrepha da região Amazônica. In: Silva, R. A.; Lemos, W. P.; Zucchi, R. A. (Eds.), Moscas-das-frutas na Amazônia Brasileira: Diversidade, Hospedeiros e Inimigos Naturais, pp. 71-90. Macapá: Embrapa Amapá.

Zucchi, R. A.; Moraes, R. C. B. (2008) Fruit flies in Brazil - Anastrepha species their host plants and parasitoids. www.lea.esalq.usp.br/ anastrepha/. Access on: 27.viii.2020. 